\title{
PENGUATAN KEWENANGAN DPD RI \\ DALAM BIDANG FUNGSI PENGAWASAN
}

\author{
Muchtar Pakpahan ${ }^{1}$
}

\begin{abstract}
$D P D$ as the state institution that be created from the spirit of reform in order to make the development of of local area fast or rapid as same as the house of representative and president so, DPD also must have an authority in discussing the draffy of laws mainly that related to the autonomy of local area, relation between the national and local area, the establishment, the enlargement, and the merger local area, the management of nature resource and other economic resource.
\end{abstract}

Kata kunci: Penguatan kewenangan DPD RI

\section{Pendahuluan}

Pada tahun 1993, saya menulis disertasi yang berjudul "PELAKSANAAN TUGAS DAN KEWAJIBAN DPR RI MASA KERJA 1982-1987" yang menjadi buku berjudul "DPR Semasa Orde Baru". Buku itu membuktikan bahwa penyelenggaraan pemerintahan selama orde baru bertentangan dengan UUD 1945, selanjutnya menyarankan perlu diadakan amandemen terhadap UUD 1945 sekaligus sebagai jawaban terhadap dua hal:

a. Pernyataan Soekarno pada pengesahan UUD 1945 "UUD ini dapat diganti setelah selesai perang asia timur raya" maksudnya Keseluruhan Perang Dunia II.

b. Kebutuhan atas kenyataan praktek ketatanegaraan yang menghasilkan banyak masalah, tidak pernah menghadirkan solusi, khususnya berkisar pada penyelenggaraan kekuasaan negara MPR (Majelis Permusyarawatan Rakyat) sebagai lembaga tertinggi negara.

Lanjutan dari buku DPR Semasa Orde Baru, saya menulis buku Potret Negara Indonesia, yang inti isi dari buku tersebut adalah perlunya perubahan melalui reformasi untuk mengamandemen UUD 1945, terutama tentang penyelenggaraan negara yang MPR sebagai lembaga tertinggi negara. Sebab kenyataannya, memposisikan MPR sebagai lembaga tertinggi negara dan memberi fungsi sebagai lembaga negara tertinggi tidak mampu memberi solusi dalam

${ }^{1}$ Guru Besar FH UKI banyak permasalahan yang dihadapi negara. Salah satu tentang fungsi Majelis Perwakilan Rakyat (MPR) yang berhubungan dengan keanggotaan yang berasal dari utusan daerah. Keadaan itu menimbulkan tuntutan utusan daerah diubah menjadi Dewan Perwakilan Daerah (DPD) yang inspirasinya dari pengalaman Senator Amerika Serikat yang sudah ditiru oleh Filippina.

Ketika mengamandemen UUD 1945 MPR masa kerja 1999-2004, pekerjaan MPR melakukan amandemen belum rampung khususnya mengenai kedudukan, fungsi dan peranan DPD RI. DPD RI kelihatannya menjadi lembaga negara yang pengadaannya melalui mekanisme demokrasi sejati, penganggarannya sama dengan DPR RI, tetapi tugasnya tidak sesuai dengan proses pengadaannya dan penganggarannya. DPD RI seperti banci.

\section{Permasalahan}

Bagaimanakah kewenanangan DPD RI dalam bidang fungsi pengawasan?

\section{Tujuan Penulisan}

Untuk mengetahui kewenangan DPD RI dalam melakukan fungsi bidang pengawasan.

\section{Kajian Konstitusi Kedudukan DPD RI}

Kajian terhadap norma dalam UUD 1945, dan UU RI No. 22 Tahun 2003 tentang Susunan dan Kedudukan MPR, DPR, DPD, dan DPRD yang memiliki kelemahan dalam menunjang Fungsi DPD dapat kita lihat sebagaimana tabel berikut : 


\begin{tabular}{|c|c|c|}
\hline No. & Aturan & Kelemahan \\
\hline \multicolumn{3}{|c|}{ Di dalam Undang Undang Dasar 1945} \\
\hline & $\begin{array}{l}\text { Pasal } 20 \text { Ayat (1) } \\
\text { Dewan Perwakilan Rakyat memegang kekuasaan } \\
\text { membentuk undang-undang. }\end{array}$ & $\begin{array}{l}\text { Seharusnya kekuasaan membentuk undang-undang } \\
\text { juga ada pada DPD, meskipun nantinya bisa dibatasi } \\
\text { pada hal-hal tertentu. }\end{array}$ \\
\hline & $\begin{array}{l}\text { Pasal } 20 \text { Ayat (2) } \\
\text { Setiap rancangan undang-undang dibahas oleh } \\
\text { Dewan Perwakilan Rakyat dan Presiden untuk men- } \\
\text { dapatkan persetujuan bersama. }\end{array}$ & $\begin{array}{l}\text { Inti kekuasaan legislatif ada pada tahap pembahasan, } \\
\text { sehingga bila DPD didesain untuk mempunyai ke- } \\
\text { kuasaan legislatife yang efektif, pasal ini juga harus } \\
\text { diubah, agar setiap RUU tidak hanya dibahas oleh DPR } \\
\text { dan Presiden, tetapi juga DPD. }\end{array}$ \\
\hline & $\begin{array}{l}\text { Pasal 22D Ayat (1) } \\
\text { Dewan Perwakilan Daerah dapat men gajukan kepa- } \\
\text { da Dewan Perwakilan Rakyat rancangan undang-un- } \\
\text { dang yang berkaitan dengan otonomi daerah, hubun- } \\
\text { gan pusat dan daerah, pembentukan dan pemekaran } \\
\text { serta penggabungan daerah, pengelolaan sumber } \\
\text { daya alam dan sumber daya ekonomi lainnya, serta } \\
\text { yang berkaitan dengan perimbangan keuangan pusat } \\
\text { dan daerah. }\end{array}$ & $\begin{array}{l}\text { Kata "dapat" membuat DPD tidak mempunyai keku- } \\
\text { asaan legislatif yang efektif. DPD tidak menjadi salah } \\
\text { satu institusi yang mengajukan RUU. } \\
\text { Pasal ini ditafsirkan ( didalamUU Susduk danUU 10/2004 } \\
\text { tentang Pembentukan Peraturan Perundang-Undangan), } \\
\text { hanya DPR dan pemerintah yang bisa mengajukan RUU. } \\
\text { Maka RUU yang disusun oleh DPD disampaikan kepa- } \\
\text { da DPR dan bila DPR menerimanya, maka RUU tersebut } \\
\text { pun dianggap diajukan oleh DPR (karena DPD bukan pi- } \\
\text { hak yang bisa mengajukan RUU untukdibahas). }\end{array}$ \\
\hline & $\begin{array}{l}\text { Pasal 22D Ayat (2) } \\
\text { Dewan Perwakilan Daerah ikut membahas rancangan } \\
\text { undang-undang yang berkaitan dengan otonomi daerah; } \\
\text { hubungan pusat dan daerah; pembentukan, pemekaran, } \\
\text { dan penggabungan daerah; pengelolaan sumber daya } \\
\text { alam dan sumber daya ekonomi lainnya, serta perim- } \\
\text { bangan keuangan pusat dan daerah; serta memberikan } \\
\text { pertimbangan kepada Dewan Perwakilan Rakyat atas } \\
\text { rancangan undang-undang anggaran pendapatan dan } \\
\text { belanja Negara dan rancangan undang-undang yang } \\
\text { berkaitan dengan pajak, pendidikan, dan agama. }\end{array}$ & $\begin{array}{l}\text { Kata "ikut" membahas rancangan RUU membuat DPD } \\
\text { tidak mempunyai kekuasaan legislatif yang efektif. } \\
\text { Pasal ini ditafsirkan ( didalam UU Susbud, UU 10/2004, } \\
\text { dan tata tertib DPR), DPD bisa saja di undang oleh DPR } \\
\text { pada awal pembahasan. Namun DPD tidak dapat ikut } \\
\text { serta dalam rapat-rapat berikutnya, terutama yang ber- } \\
\text { kaitan dengan pengambilan keputusan. }\end{array}$ \\
\hline & $\begin{array}{l}\text { Pasal 22DAyat (3) } \\
\text { Dewan Perwakilan Rakyat Daerah dapat melakukan } \\
\text { pengawasan atas pelaksanaan undang-undang men- } \\
\text { genai; otonomi daerah, pembentukan, pemekaran } \\
\text { dan penggabungan daerah, hubungan pusat dan dae- } \\
\text { rah pengelolaan sumber daya alam dan sumber daya } \\
\text { ekonomi lainnya, pelaksanaan anggaran pendapatan } \\
\text { dan belanja Negara, pajak, pendidikan, dan agama } \\
\text { serta menyampaikan hasil pengawasannya itu kepa- } \\
\text { da Dewan Perwakilan Rakyat sebagai bahan pertim- } \\
\text { bangan untuk ditindak lanjuti. }\end{array}$ & $\begin{array}{l}\text { Kata "dapat" membuat DPD tidak mempunyai keku- } \\
\text { asaan yang efektif dalam hal pengawasan atas pelak- } \\
\text { saaan undang-undang. } \\
\text { Pasal ini ditafsirkan sedemikian rupa sehingga masukan } \\
\text { dari DPD dalam hal fungsi pengawasan juga tidak diter- } \\
\text { jemahkan ke dalam mekanisme yang jelas yang mem- } \\
\text { buat masukan tersebut efektif. }\end{array}$ \\
\hline & $\begin{array}{l}\text { Pasal } 23 \text { Ayat (2) } \\
\text { Rancangan undang-undang anggaran pendapatan } \\
\text { dan belanja Negara diajukan oleh presiden untik di- } \\
\text { bahas bersama Dewan Perwakilan Rakyat dengan } \\
\text { memperhatikan pertimbangan dewan perwakilan } \\
\text { daerah. }\end{array}$ & $\begin{array}{l}\text { Frase "dengan memperhatikan pertimbangan DPD" } \\
\text { membuat DPD tidak mempunyai kekuasaan yang efek- } \\
\text { tif dalam hal fungsi anggaran. }\end{array}$ \\
\hline
\end{tabular}




\begin{tabular}{|c|c|}
\hline $\begin{array}{l}\text { Pasal } 23 \text { Ayat (3) } \\
\text { Apabila Dewan Perwakilan Rakyat tidak menyetujui } \\
\text { rancangan anggaran pendapatan dan belanja Negara } \\
\text { yang diusulkan oleh presiden, pemerintah menjalan- } \\
\text { kan anggaran pendapatan dan belanja Negara tahun } \\
\text { yang lalu. }\end{array}$ & $\begin{array}{l}\text { DPD tidak dimasukan di dalam ketentuan ini sehingga } \\
\text { fungsi anggaran DPD semakin tidak efektif karena ma- } \\
\text { sukan DPD semakin tidak didengar. }\end{array}$ \\
\hline $\begin{array}{l}\text { Pasal 23F Ayat (1) } \\
\text { Anggota Badan Pemeriksa Keuangan dipilih oleh } \\
\text { Dewan Perwakilan Rakyat dengan memperhatikan } \\
\text { pertimbangan Dewan Pertimbangan Daerah dan di- } \\
\text { resmikan oleh presiden. }\end{array}$ & $\begin{array}{l}\text { Seharusnya pertimbangan DPD menjadi elemen uta- } \\
\text { ma, bukan hanya diperhatikan oleh DPR. Ketentuan ini } \\
\text { berkontribusi kepada tidak efektifnya wewenang DPD } \\
\text { dalam hal fungsi anggaran dan pengawasan. }\end{array}$ \\
\hline \multicolumn{2}{|c|}{ Di dalam UU No.22 Tahun 2003 tentang Susunan dan Kedudukan MPR, DPR, DPD dan DPRD } \\
\hline $\begin{array}{l}\text { Pasal } 41 \\
\text { DPD mempunyai fungsi : } \\
\text { Pengajuan usul, ikut dalam pembahasan dan mem- } \\
\text { berikan pertimbangan yang berkaitan dengan bidang } \\
\text { legislasi tertentu; } \\
\text { Pengawasan atas pelaksanaan undang-undang ter- } \\
\text { tentu. }\end{array}$ & $\begin{array}{l}\text { DPD dianggap hanya "ikut" dalam pembahasan (tidak } \\
\text { "membahas" dalam arti turut memutuskan). }\end{array}$ \\
\hline $\begin{array}{l}\text { Pasal } 42 \text { Ayat (1) } \\
\text { DPD dapat mengajukan kepada DPR rancangan un- } \\
\text { dang-undang yang berkaitan dengan otonomi dae- } \\
\text { rah, hubungan pusat dan daerah, pembentukan dan } \\
\text { pemekaran, dan penggabungan daerah, pengelolaan } \\
\text { sumber daya alam, dan sumber daya ekonomi lainnya } \\
\text { serta yang berkaitan dengan perimbangan keuangan } \\
\text { pusat dan daerah. }\end{array}$ & $\begin{array}{l}\text { Kata "dapat" membuat DPD tidak mempunyai keku- } \\
\text { asaan legislatif yang efektif. DPD tidak menjadi salah } \\
\text { satu institusi yang mengajukan RUU. } \\
\text { Ayat selanjutnya dalam pasal ini membuat wewenang } \\
\text { DPD semakin kecil. }\end{array}$ \\
\hline $\begin{array}{l}\text { Pasal } 42 \text { Ayat (2) } \\
\text { DPD mengusulkan rancangan undang-undang seba- } \\
\text { gaimana dimaksud pada ayat (1) kepada DPR dan } \\
\text { DPR mengundang DPD untuk membahas sesuai tata } \\
\text { tertib DPR. }\end{array}$ & $\begin{array}{l}\text { Kententuan ini memberikan kekuasaaan penuh kepada } \\
\text { DPR untuk menentukan kapan DPD bisa diundang dan } \\
\text { menetukan lebih jauh relasi antara DPR dan DPD di da- } \\
\text { lam peraturan internela DPR. }\end{array}$ \\
\hline $\begin{array}{l}\text { Pasal } 42 \text { Ayat (3) } \\
\text { Pembahasan rancangan undang-undang sebagaima- } \\
\text { na dimaksud pada ayat (2) dilakukan sebelum DPR } \\
\text { membahas rancangan undang-undang dimaksud } \\
\text { pada ayat (1) dengan pemerintah. }\end{array}$ & $\begin{array}{l}\text { Ketentuan ini semakin mengecilkan efektivitas fungsi } \\
\text { legislasi DPD karena DPD hanya dapat diundang sebe- } \\
\text { lum pembahasan RUU yang sesungguhnya dimulai. }\end{array}$ \\
\hline $\begin{array}{l}\text { Pasal } 43 \text { Ayat (1) } \\
\text { DPD ikut membahas rancangan undang-undang } \\
\text { yang berkaitan dengan otonomi daerah; hubungan } \\
\text { pusat dan daerah; pembentukan, pemekaran, dan } \\
\text { penggabungan daerah; pengelolaan sumber daya } \\
\text { alam, dan sumber daya ekonomi lainnya serta yang } \\
\text { berkaitan dengan perimbangan keuangan pusat dan } \\
\text { daerah, yang diajukan baik oleh DPR maupun oleh } \\
\text { pemerintah. }\end{array}$ & $\begin{array}{l}\text { Kata "ikut" membahas RUU membuat DPD tidak mem- } \\
\text { punyai kekuasaaan legislatif yang efektif. }\end{array}$ \\
\hline
\end{tabular}




\begin{tabular}{|c|c|}
\hline $\begin{array}{l}\text { Pasal } 43 \text { Ayat (2) } \\
\text { DPD diundang oleh DPR untuk melakukan pemba- } \\
\text { hasan rancangan undang-undang sebagaimana di- } \\
\text { maksud pada ayat (1) bersama dengan pemerintah } \\
\text { pada awal Pembicaraan Tingkat I sesuai Peraturan } \\
\text { Tata Tertib DPR. }\end{array}$ & $\begin{array}{l}\text { Ketentuan ini semkin mengecilkan efektivitas fungsi } \\
\text { legislasi DPD karena DPD hanya dapat diundang se- } \\
\text { belum pembahasan RUU yang sesungguhnya dimulai. } \\
\text { Ketentuan ini juga memberikan kekuasaan penuh kepa- } \\
\text { da DPR untuk menentukan lebih jauh relasi antara DPR } \\
\text { dan DPD dengan memuatnya di dalam peraturan DPR. }\end{array}$ \\
\hline $\begin{array}{l}\text { Pasal } 43 \text { ayat (3) } \\
\text { Pembicaraan Tingkat I sebagaimana dimaksud pada } \\
\text { ayat (2) dilakukan bersama antara DPR, DPD, dan } \\
\text { pemerintah dalam hal penyampaian pandangan dan } \\
\text { pendapat DPD atas rancangan undang-undang, ser- } \\
\text { ta tanggapan atas pandangan dan pendapat dari ma- } \\
\text { sing-masing lembaga. }\end{array}$ & $\begin{array}{l}\text { Ketentuan ini merupakan elaborasi lebih jauh dari ayat } \\
\text { sebelumnya (di atas) sehingga semakin mengecilkan } \\
\text { efektivitas fungsi legislasi DPD. }\end{array}$ \\
\hline $\begin{array}{l}\text { Pasal } 43 \text { ayat (4) } \\
\text { Pandangan, pendapat, dan tanggapan sebagaimana } \\
\text { dimaksud pada ayat (3) dijadikan sebagai masukan } \\
\text { untuk pembahasan lebih lanjut antara DPR dan pe- } \\
\text { merintah. }\end{array}$ & $\begin{array}{l}\text { Ketentuan ini merupakan elaborasi lebih jauh dari ayat } \\
\text { sebelumnya (di atas) sehingga semakin mengecilkan } \\
\text { efektivitas fungsi legislasi DPD. }\end{array}$ \\
\hline $\begin{array}{l}\text { Pasal } 4 \text { ayat (1) } \\
\text { DPD memberikan pertimbangan kepada DPR atas } \\
\text { rancangan undang-undang APBN dan rancangan un- } \\
\text { dang-undang yang berkaitan dengan pajak, pendidi- } \\
\text { kan, dan agama. }\end{array}$ & $\begin{array}{l}\text { Ketentuan ini semakin mengecilkan efektivitas fungsi } \\
\text { legislasi dan fungsi anggaran DPD karena DPD hanya } \\
\text { dapat memberikan pertimbangan. }\end{array}$ \\
\hline $\begin{array}{l}\text { Pasal } 44 \text { ayat (2) } \\
\text { Pertimbangan sebagaimana dimaksud pada ayat (1) } \\
\text { diberikan dalam bentuk tertulis sebelum memasuki } \\
\text { tahapan pembahasan antara DPR dan pemerintah. }\end{array}$ & $\begin{array}{l}\text { Ketentuan ini merupakan elaborasi lebih jauh dari ayat } \\
\text { sebelumnya (di atas) sehingga semakin mengecilkan } \\
\text { efektivitas fungsi legislasi DPD. Sebab DPD hanya } \\
\text { memberikan pertimbangan sebelum pembahasan RUU } \\
\text { yang sesungguhnya di mulai. }\end{array}$ \\
\hline $\begin{array}{l}\text { Pasal } 44 \text { ayat ( } 3 \text { ) } \\
\text { Pertimbangan sebagaimana dimaksud pada ayat (1) } \\
\text { menjadi bahan bagi DPR dalam melakukan pemba- } \\
\text { hasan dengan pemerintah. }\end{array}$ & $\begin{array}{l}\text { Ketentuan ini menguatkan lagi bahwa pertimbangan itu } \\
\text { hanya "bahan" bagi DPR sehingga semakin mengecil- } \\
\text { kan efektivitas fungsi legislasi dan fungsi anggaran } \\
\text { DPD. }\end{array}$ \\
\hline $\begin{array}{l}\text { Pasal } 45 \text { ayat (1) dan ayat (2) } \\
\text { DPD memberikan pertimbangan kepada DPR dalam } \\
\text { memilihan anggota Badan Pemeriksa Keuangan. } \\
\text { Pertimbangan sebagaimana dimaksud pada ayat (1) } \\
\text { disampaikan secara tertulis sebelum pemilihan an- } \\
\text { ggota Badan Pemeriksa Keuangan. }\end{array}$ & $\begin{array}{l}\text { Seharusnya pertimbangan DPD menjadi elemen uta- } \\
\text { ma, bukan hanya diperhatikan oleh DPR dan disampain } \\
\text { sebelum pemilihan anggota BPK yang sesungguhnya } \\
\text { dimulai. Ketentuan ini berkontribusi kepada tidak efe- } \\
\text { tifnya wewenang DPD dalam hal fungsi anggaran dan } \\
\text { pengawasan. }\end{array}$ \\
\hline $\begin{array}{l}\text { Pasal } 46 \text { ayat (1) } \\
\text { DPD dapat melakukan pengawasan atas pelaksanaan } \\
\text { undang-undang mengenai otonomi daerah, pemben- } \\
\text { tukan, pemekaran, dan penggabungan daerah, hu- } \\
\text { bungan pusat dan daerah, pengelolaan sumber daya } \\
\text { alam, dan sumber daya ekonomi lainnya, pelaksa- } \\
\text { naan APBN, pajak, pendidikan, dan agama. }\end{array}$ & $\begin{array}{l}\text { Fakta "dapat" membuat DPD tidak mempunyai keku- } \\
\text { asaan yang efektif dalam hal pengawasan atas pelaksa- } \\
\text { naan undang-undang. }\end{array}$ \\
\hline $\begin{array}{l}\text { Pasal } 46 \text { ayat (3) } \\
\text { Hasil pengawasan sebagaimana dimaksud pada ayat } \\
\text { (1) disampaikan kepada DPR sebagai bahan pertim- } \\
\text { bangan untuk ditindak lanjuti. }\end{array}$ & $\begin{array}{l}\text { Ketentuan ini merupakan eleborasi lebih lanjut dari } \\
\text { pasal } 46 \text { ayat (1) di atas yang menguatkan interpretasi } \\
\text { bahwa hasil pengawasan DPD hanya merupakan bahan } \\
\text { pertimbangan bagi DPR. Akibatnya, fungsi pengawa- } \\
\text { san DPD tidak efektif. }\end{array}$ \\
\hline
\end{tabular}




\section{Fungsi DPD pada Kenyataannya}

\section{Fungsi Legislasi DPD RI}

Selama dua periode keanggotaan, DPD telah menghasilkan 57 (lima puluh tujuh) usul RUU. Dari 57 RUU yang dihasilkan DPD, hanya satu RUU yang ditindaklanjuti oleh DPR yakni RUU tentang kelautan yang saat ini telah disahkan menjadi UU No. 32 Tahun 2014. Pada diktum mengingat UU Nomor 32 Tahun 2014 tersebut telah mencantumkan pasal 22D ayat (1). Sedangkan sisa 56 RUU lainnya yang telah disampaikan ke DPR belum pernah ada penjelasan ataupun jawaban tertulis dari DPR pada DPD mengenai nasib RUU tersebut. Bahkan ada beberapa RUU dari DPD periode lalu menjadi usul inisiatif DPR seperti RUU tentang Lembaga Keuangan Mikro yang telah disahkan menjadi UU No. 1 tahun 2013, dan RUU tentang kepelabuhan yang telah disahkan menjadi UU No. 17 tahun 2008. Kedua UU tersebut pada diktum mengingat tidak mencantumkan pasal 22D ayat (1). Dengan kata lain, RUU tersebut telah "berganti baju" dari statusnya sebagai usulan DPD menjadi usulan DPR.

Perlu disadari bahwa sudah saatnya bagi DPR sebagai pemegang kekuasaan legislasi bebagi peran dengan DPD dalam perencanaan dan penyusunan undang-undang mengingat banyak UU yang telah dihasilkan DPR dan pemerintah dibatalkan oleh Mahkamah Konstitusi karena dianggap bertentangan dengan UUD 1945. Hal tersebut menurut Mahfud MD karena terjadi penurunan kualitas UU. Turunnya kualitas UU yang dibuat oleh pemerintah dan DPR disebabkan oleh beberapa indikasi. Indikasi itu adalah adanya ketidak profesionalan pembuat UU dan kuatnya politik transaksional ${ }^{2}$. Dalam situasi seperti itu semestinya DPR harus sadar bahwa mereka membutuhkan partner dalam perencanaan dan penyusunan RUU sehingga peran ini harus mulai diserahkan DPR kepada DPD untuk menjamin efektivitas dan efisiensi legislasi.

UUD membatasi ruang lingkup dan kewenangan DPD dalam fungsi legislasi. Dari segi ruang lingkup, konstitusi membatasi fungsi legislasi DPD hanya terkait otonomi daerah, hubungan pusat dan daerah, pembentukan, pemekaran, dan penggabungan daerah, pengelolaan sumber daya alam, dan sumber daya lainnya, dan sumber daya ekonomi lainnya, serta yang berkaitan dengan perimbangan keuangan pusat dan daerah. Kebijakan tersebut melahirkan pertanyaan apakah sebagai wakil daerah DPD tidak dapat diberi peran untuk juga

\footnotetext{
${ }^{2}$ http://www.merdeka.com/peristiwa/banyak-dibatalkan-mk-kualitas-legislasi-2012-menurun.html
}

melaksanakan fungsi legislasi yang menyangkut UU lain? (misalnya dalam UU tentang intelijen, UU Kejaksaan/POLRI/KPK, KUHP/KUHAP, dan lain-lain). Dari segi kewenangan, konstitusi membatasi DPD hanya sebatas memberikan pandangan dan pendapat serta pertimbangan kepada DPR. Kebijakan tersebut menimbulkan pertanyaan apakah sebagai wakil rakyat yang anggotanya juga ikut dipilih bersama-sama anggota DPR, DPD tidak dapat mempunyai wewenang sampai pada tahap pengambilan keputusan?

Selain permasalahan tersebut, DPD juga menghadapi pandangan skeptic dari para politisi yang menganggap bahwa DPD bukan merupakan bagian dari parlemen. Jika demikian halnya, apakah kedudukan DPD sebagai lembaga perwakilan daerah bukan merupakan bagian dari parlemen, padahal UndangUndang Dasar 1945 hasil amandemen menentukan bahwa DPD dapat mengajukan kepada DPR rancangan Undang-undang yang berkaitan dengan otonomi daerah, hubungan pusat dan daerah, pembentukan dan pemekaran serta penggabungan daerah, pengelolaan sumber daya alam dan sumber daya ekonomi lainnya, serta yang berkaitan dengan perimbangan keuangan pusat dan daerah. ${ }^{3}$

\section{Fungsi Pengawasan DPD RI}

Terkait dengan fungsi pengawasan, Pasal 22D ayat (3) UUD 1945 menyatakan bahwa DPD dapat melakukan pengawasan atas pelaksanaan undang-undang mengenai: (a) Otonomi daerah, (b) Hubungan Pusat dan Daerah, (c) pembentukan dan pemekaran serta penggabungan daerah, (d) Pengelolaan Sumber Daya Alam dan Sumber Daya Ekonomi lainnya, (e) Pelaksanaan Anggaran Pendapatan dan Belanja Negara, (f) Pajak, (g) Pendidikan, dan (h) Agama. Kemudian, hasil itu disampaikan kepada DPR sebagai bahan pertimbangan untuk ditindak lanjuti.

Dalam Pasal 249 Ayat (1) huruf e UU MD3 menyatakan bahwa DPD dapat melakukan pengawasan atas pelaksanaan undang-undang mengenai otonomi daerah, pembentukan, pemekaran, dan penggabungan daerah, hubungan pusat dan daerah, pengelolaan sumber daya alam, dan sumber daya ekonomi lainnya, pelaksanaan APBN, pajak, pendidikan, dan agama. Sedangkan huruf $\mathrm{f}$ disebutkan hasil pengawasan atas pelaksanaan undang-undang tertentu disam-

\footnotetext{
${ }^{3}$ Priyatmoko, Hubungan Kerja dan Mekanisme Kerja DPD dengan DPR dan Lembaga-Lembaga Negara lain. dalam Dewan Perwakilan Daerah, dalam Sistem Ketatanegaraan Republik Indonesia, Editor Janedjri M. Gaffar et al, Jakarta: Sekretariat Jenderal MPR, 2004, h 137
} 
paikan kepada DPR sebagai bahan pertimbangan untuk ditindaklanjuti. Kemudia Pasal 284 Ayat (1) dan

(2) UUD MD3, menyatakan bahwa dalam rangka pelaksanaan wewenang dan tugas, DPD menyampaikan hasil pengawasan, yang telah diputuskan dalam sidang paripurna DPD, atas pelaksanaan undang-undang kepada DPR sebagai bahan pertimbangan.

Frasa "bahan pertimbangan untuk ditindaklanjuti", mengindikasikan lemahnya posisi DPD seolaholah menjadi subordinat DPR. Ketentuan Pasal 22D tidak mengikat DPR untuk menindaklanjuti hasil pengawasan DPD. Hal ini terbukti, selama 2 periode keanggotaan DPD (2004-2009 dan 2009-2014), DPD telah menghasilkan 138 buah hasil pengawasan namun tidak satu pun yang ditindaklanjuti DPR. Padahal, DPR melalui tatibnya mengadopsi ketentuan pada Pasal 6 huruf f UU MD3 yang menyatakan bahwa DPR berwenang membahas dan menindaklanjuti hasil pengawasan yang disampaikan oleh DPD atas pelaksanaan undang-undang mengenai otonomi daerah, pembentukan, pemekaran dan penggabungan daerah, hubungan pusat dan daerah, pengelolaan sumber daya alam dan sumber daya ekonomi lainnya, pelaksanaan APBN, pajak, pendidikan, dan agama.

Pasal 58 Ayat (3) huruf e tata tertib DPR menegaskan tugas komisi DPR dalam bidang pengawasan yakni : membahas dan menindaklanjuti usulan DPD. Tugas tersebut dimaknai oleh DPR bahwa tidak menindaklanjuti hasil pengawasan DPD bukan suatu pelanggaran bagi DPR.

Fungsi pengawasan DPR adalah pengawasan atas pelaksanaan undang-undang, APBN, dankebijakan pemerintah. Dalam melaksanakan fungsi pengawasan, DPR melalui alat kelengkapannya dapat melakukan rapat kerja dengan pemerintah, pejabat pemerintah yang mewakili instansi, ataupun pihak-pihak lainnya guna memperoleh keterangan terhadap suatu persoalan. Hasil atau kesimpulan rapat bersifat mengikat antara DPR dengan pemerintah serta wajib dilaksanakan oleh pemerintah. Kemudian, dalam pengawasan keuangan Negara, DPR dapat membahas laporan keuangan pemerintah pusat yang telah diaudit oleh BPK serta dapat melakukan konfirmasi kepada pemerintah terkait hasil pemeriksaan semester BPK. Pemnerintah harus memperhatikan hasil pengawasan DPR. Selain fungsi pengawasan, DPR juga memiliki hak interplasi dan hak angket PP. Hak interplasi merupakan hak untuk meminta keterangan kepada pemerintah mengenai kebijakan pemerintah yang penting dan strategis serta berdampak luas pada kehidupan bermasyarakat, berbangsa, dan bernegara. Hak angket adalah hak untuk melakukan penyelidikan terhadap pelaksanaan suatu undang-undang dan/atau kebijakan pemerintah yang berkaitan dengan hal penting, strategis, dan berdampak luas pada kehidupan bermasyarakat, berbangsa, dan bernegara yang diduga bertentangan dengan peraturan perundang-undangan.

DPD hanya memiliki fungsi pengawasan terhadap pelaksanaan UU tertentu. Dalam rangka pelaksanaan fungsi pengawasan, komite sebagai alat kelengkapan DPD dapat melakukan rapat kerja dengan pemerintah, pejabat pemerintah yang mewakili instansinya, atau pihak yang terkait lainnya guna meminta keterangan terhadap suatu pemasalahan. Komite dapat mengumpulkan data dan bahan keterangan tentang pelaksanaan setiap ketentuan UU serta memberikan rekomendasi terhadap suatu permasalahan. Namun, rekomendasi komite tersebut tidak memiliki daya ikat kepada pemerintah. Pengawasan yang dibuat oleh DPD menghabiskan tenaga dan biaya yang jumlahnya tidak sedikit dan semestinya bisa menjadi alat control daerah terhadap pelaksanaan pembangunan yang dijalankan oleh pemerintah. Dalam hal pengawasan keuangan Negara, DPD hanya berwenang melakukan hasil pengawasan terhadap UU tentang APBN yang selanjutnya disampaikan kepada DPR, DPR sebagai bahan pertimbangan untuk ditindaklanjuti sebagaimana yang tertulis dalam pasal 249 ayat (1) huruf f UU MD3. DPD juga tidak memiliki hak interplasi dan hak angket sebagaimana yang dimiliki DPR dalam rangka mengawal kepentingan daerah dipusat. Dari keterangan diatas jelas terlihat betapa superioritas DPR diatas DPD. Pertanyaan besar yang perlu dijawab yakni bagaimana idealnya fungsi pengawasan yang dimiliki DPD untuk meningkatkan partisipasi daerah dalam pembangunan nasional?

Terkait fungsi pengawasan, sebagaimana dengan fungsi legislasi, ruang lingkup kewenangan DPD dibatasi hanya menyangkut UU otonomi daerah, pembentukan, pemekaran dan penggabungan daerah, hubungan pusat dan daerah, pengelolaan sumber daya alam dan sumber daya ekonomi lainnya. Sebagaimana ketentuan dalam UUD 1945, hasil pengawasan yang dilakukan DPD disampaikan kepada DPR. Dalam pelaksanaannya kewenangan DPD dalam fungsi pengawasan tersebut tidak ditindaklanjuti oleh DPR. Hal ini menimbulkan pertanyaan, apakah fungsi pengawasan DPD perlu diperkuat mekanisme tidak lanjutnya baik kepada DPR maupun kepada pemerintah? Apakah DPD perlu diberi peningkatan kewenangan dalam fungsi pengawasan? Sejauh mana peningkatan fungsi pengawasan yang diberikan kepada DPD.

Berkaitan dengan hal itu, fungsi pengawasan ideal yang harus dimiliki DPD dalam mekanisme check and balance yang lebih baik adalah, apabila 
DPD diberikan fungsi untuk tidak saja mengawasi pelaksanaan UU secara formal, tetapi juga mengawasi secara substansial, apa yang merupakan kehendak dari undang-undang tersebut, terutama dikaitkan dengan kebijakan-kebijakan publik yang diambil pemerintah sesuai dengan misi atau tujuan yang tertuang di dalam undang-undang tersebut. Dengan demikian, maka fungsi pengawasan dan fungsi legislatif yang dijalankan oleh DPD dapat dilaksanakan secara beriring. Disinilah diciptakan titik pertautan antara kedua fungsi yang dimiliki oleh DPD. ${ }^{4}$

\section{Fungsi Pertimbangan DPD RI}

Fungsi pertimbangan DPD sesuai dengan Pasal 248 angka (1) huruf d UU Nomor 17 Tahun 2014, menyatakan DPD mempunyai fungsi pemberian pertimbangan kepda DPR atas rancangan undang-undang tentang anggaran pendapatan dan belanja Negara dan rancangan undang-undang yang berkaitan dengan pajak, pendiidkan, dan agama. Lebih lanjut, fungsi DPD ini dilaksanakan oleh alat kelengkapan berupa panitia kerja, yang tugasnya melakukan pembahasan dan penyusunan pertimbangan DPD mengenai rancangan undang-undang tentang APBN.

Dalam hal ini, fungsi pertimbangan DPR RI harus dapat terwujud dalam proses pembahasan rancangan undang-undang dan pendapatan belanja negara dan rancangan undang-undang yang berkaitan dengan pendidikan dan agama yang dilakukan oleh DPR dan Presiden, DPD harus memberikan pertimbangan yang dapat dipertanggungjawabkan kepada DPR. Pertimbangan yang disampaikan itu harus dipikirkan secara matang, rasional dan realistis dengan maksud agar fungsi pertimbangan DPD itu bisa berdampak positif dalam meningkatkan akselerasi pembangunan di semua bidang. ${ }^{5}$

\section{Fungsi Anggaran DPD RI}

Posisi DPD dalam anggaran negara hanya sebatas pemberi pertimbangan. Sedangkan posisi DPR dalam tugas anggaran yang dijalankan oleh komisi dan badan anggaran memiliki kewenangan yang luas dan kuat dalam pembahasan dan pengesahan Rancangan Anggaran Pendapatan dan Belanja Negara.

\footnotetext{
${ }^{4}$ John Pieris dan Aryanthi Baramuli Putri, Dewan Perwakilan Dae rah Republik Indonesia, Studi, Analisis, Kritik dan Solusi Kajian Hukum dan Politik, Jakarta: Pelangi Cendekia, 2006, h 174.

${ }_{5}^{5}$ John Pieris dan Aryanthi Baramuli Putri, Penguatan Dewan Perwakilan Daerah Republik Indonesia. Beberapa Langkah Strategis Kajian Hukum Tata Negara dan Politik (Memotong Spiral Kekuasaan), Jakarta: Pelangi Cendekia, 2009, h 298.
}

Dengan demikian, maka kedudukan parlemen sebagai bentuk kedaulatan rakyat memiliki posisi sebgai pihak yang ikut serta dalam pembahasan Rancangan Anggaran Pendapatan dan Belanja Negara, walaupun dalam konteks ini, DPD masih ditempatkan pada posisi yang lemah, karena hanya memberikan pertimbangan ketika pembahasan rancangan undang-undang APBN. Padahal, pertimbangan hanyalah sebagian kecil saja penggunaan hak dalam fungsi anggaran. Semestinya, DPD yang lahir guna menjamin mekanisme Chek and balances di antara kedua kamar/majelis dapat berjalan lebih seimbang diberi kewenangan untuk mengusulkan, mempertimbangkan, mengubah, dan menetapkan anggaran seperti DPR

\section{Penguatan Fungsi Pengawasan DPD RI}

\section{Fungsi DPD RI menurut UUD}

Pasal 22D Ayat (3) UUD 1945 menyatakan bahwa DPD dapat melakukan pengawasan atas pelaksanaan undang-undang mengenai: (a) Otonomi daerah, (b) Hubungan Pusat dan Daerah, (c) pembentukan dan pemekaran serta penggabungan daerah, (d) Pengelolaan Sumber Daya Alam dan Sumber Daya Ekonomi lainnya, (e) Pelaksanaan Anggaran Pendapatan dan Belanja Negara, (f) Pajak, (g) Pendidikan, dan (h) Agama. Kemudian, hasil itu disampaikan kepada DPR sebagai bahan pertimbangan untuk ditindak lanjuti.

Fungsi pengawasan dengan didahului kata "dapat" dilanjutkan dengan "melakukan pengawasan", adalah memiliki beberapa kelamahan. 1. Sebagai aturan dasar pasal ini memberi fungsi yang lemah seakan-akan opsi boleh dilakukan dan boleh tidak dilakukan, bukan merupakan perintah. 2. Pengawasan yang dilakukan oleh DPD disampaikan kepada DPR sebagai bahan pertimbangan untuk ditindaklanjuti. Dapat diperkirakan DPR yang perwakilan kepentingan politik tidak akan menindaklanjutinya bila bersentuhan dengan kepentingan politik, serta bila bersentuhan dengan persaingan "terselubung" DPD RI dengan DPR RI.

\section{Fungsi DPD RI yang diharapkan}

Pengawasan yang dilakukan DPD RI adalah terkait langsung dan tidak langsung kepada kehidupan dan mutu hidup manusia, masyarakat dan rakyat Indonesia. Sebab yang diawasi adalah mengenai: (a) otonomi daerah, (b) hubungan pusat dan daerah, (c) pembentukan dan pemekaran. (d) pengelolaan sumber daya alam dan sumber daya ekonomi lainnya, (e) 
Pelaksanaan Anggaran Pendapatan dan Belanja Ne- gara, (f) pajak, (g) Pendidikan, dan (h) agama. Dapat dikatakan pengawasan (a), (b) dan (c) berhubungan dengan kepentingan partai politik. Butir (d) dan (e) bisa dimasukkan menjadi kepentingan partai politik, bisa kepentingan bisnis yang menunggangi atau di- tunggangi partai politik, dan bisa bisnis murni. Se- dangkan (f), (g) dan (h) adalah kategori kepentingan rakyat, masyarakat dan hajat hidup setiap pribadi ma- nusia Indonesia.

Nasib setiap anggota DPD RI akan tergantung langsung kepada aspirasi rakyat yang diwakili, kare- na itu dia akan sungguh-sungguh mendengar aspira- si rakyat. Beda dengan DPR RI, ketergantungannya adalah pada sikap pimpinan partai. Karena itu bisa terjadi rakyat yang diwakili marah dengan korupsi lalu mendukung KPK, tetapi anggota DPRnya men- dukung pelemahan KPK, diharapkan semangat refor- masi, DPD berperan seperti Senat USA. Pengawasan terhadap (a) sampai (h), langsung dilakukan ke in- stansi yang diawasi, dan bila dibawa dalam sidang MPR.

\section{Penguatan Fungsi Pengawasan DPD RI}

a. Perlu perubahan terhadap Pasal 22 D UUD de- ngan menghilangkan kata "dapat" supaya berubah menjadi perintah atau penugasan kepada DPD RI, hasil temuannya dikordinasikan dengan instansi terkait dan dibawa ke sidang MPR.

b. Perlu ada upaya-upaya untuk menempuh aman- demen Pasal 22 D UUD.

\section{Kesimpulan}

Berdasarkan uraian diatas, maka dapat dikata- kan bahwa kewenangan DPD RI dalam melakukan tugasnya atau fungsinya seperti : Fungsi Legislasi, Fungsi Pengawasan, Fungsi, Fungsi Pertimbangan, begitupun Fungsi Anggaran, ternyata belum optimal bahkan terkesan belum berjalan sebagaimana di amanatkan oleh Undang-undang Dasar 1945.

\section{Saran}

Untuk mengoptimumkan dan memaksimumkan fungsi dan peranan DPD, secara khusus fungsi pengawasan, perlu ditempuh beberapa langkah seperti berikut ini: (a) Para Anggota DPD secara sungguhsungguh mengadvokasi kepentingan rakyat banyak, terutama fungsi pengawasan terhadap butir (a) sampai (h). Misalnya saat ini PP Nomor: 44, 45 dan 46 tahun 2015 dan RPP Pengupahan. Hal ini menyang- kut nasib 65\% angkatan kerja rakyat Indonesia; (b) DPD secara kelembagaan melakukan upaya sosiali- sasi seoptimum dan semaksimum mungkin, baik me- lalui menggunakan media maupun bertemu dengan DPRD Kota/kabupaten, DPRD Provinsi, dan orga- nisasi kemasyarakatan serta LSM di tingkat daerah. Saya rekomendasikan misalnya sosialisasi kerjasa- ma dengan Serikat Buruh/Pekerja.(c) diusahakan menciptakan bahwa mengoptimumkan dan memak- simumkan peranan dan fungsi DPD adalah kebutu- han rakyat banyak. Untuk itu perlu dibuka dialog organisasi buruh, tani dan nelayan serta organisasi mahasiswa, yang sekaligus sinergi. Hal ini untuk memberikan fungsi dan peranan DPD yang optimum dan maksimum yang dapat mengisi kekecewaan terhadap perwakilan DPRRI. Karena DPRRI adalah penentu pemberi peranan dan fungsi DPD, yakinkan rakyat untuk menekan DPRRI, agar amandemen Pa- sal 22 D dapat terwujud.

\section{Daftar Pustaka}

http://www.merdeka.com/peristiwa/banyak-dibatal- kan-mk-kualitas-legislasi-2012-menurun.html

Priyatmoko, Hubungan Kerja dan Mekanisme Ker- ja DPD dengan DPR dan Lembaga-Lembaga Negara lain. dalam Dewan Perwakilan Dae- rah, dalam Sistem Ketatanegaraan Republik Indonesia, Editor Janedjri M. Gaffar et al, Ja- karta: Sekretariat Jenderal MPR, 2004

John Pieris dan Aryanthi Baramuli Putri, Dewan Perwakilan Daerah Republik Indonesia, Studi, Analisis, Kritik dan Solusi Kajian Hukum dan Politik, Jakarta: Pelangi Cendekia, 2006

John Pieris dan Aryanthi Baramuli Putri, Penguatan Dewan Perwakilan Daerah Republik Indo- nesia. Beberapa Langkah Strategis Kajian Hukum Tata Negara dan Politik (Memotong Spiral Kekuasaan), Jakarta: Pelangi

Cendekia, 2009 